\title{
DISTRIBUTION OF LICHEN SPECIES OF THE GENUS LEPRARIA IN THE KNYSZYN FOREST (NE POLAND) IN DIFFERENT FOREST PLANT COMMUNITIES
}

\author{
ANNA MatwiEJuK
}

\begin{abstract}
The aim of the study was to evaluate the distribution of lichen species of the genus Lepraria in Knyszyn Forest (NE Poland) to different forest plant communities. Six species of Lepraria [L. eburnea J. R. Laundon, L. elobata Tønsberg, L. incana (L.) Ach., L. jackii Tønsberg, L. lobificans Nyl. and L. vouaxii (Hue) R. C. Harris] recorded from Knyszyn Forest. Lepraria eburnea is a new species for the studied area. The most common species were Lepraria incana and L. lobificans. Among the studied forest communities the richest in species ( 5 species of Lepraria) were oak-hornbeam forest (Tilio-Carpinetum), and the least species-rich (2 species) were maple-linden slope forest (Aceri-Tilietum), alder carr (Carici elongatae-Alnetum) and spruce forest (Sphagno girgensohnii-Piceetum). The richest lichen diversity in the Knyszyn Forest was found on deciduous trees such as Carpinus betulus L. and Quercus robur L. (4 species), Tilia cordata Mill. (3 spp.), and conifers such as Picea abies (L.) H. Karst. and Pinus sylvestris L. (3 spp.).
\end{abstract}

Key words: biodiversity, lichenized fungi, sterile lichens, secondary substances, lowland forests, new records

Anna Matwiejuk, Department of Plant Ecology, Institute of Biology, University of Bialystok, Konstanty Ciolkowski 1J street, 15-234 Bialystok, Poland; e-mail: matwiej@uwb.edu.pl

\section{INTRODUCTION}

The species of the genus Lepraria Ach. are lichenized fungi consisting of a persistently sterile crustose sorediate thallus. Lepraria is an evolutionarily successful genus of 61 species with a worldwide distribution (Saag et al. 2009). Reduced morphology in Lepraria has made species difficult to define; consequently, secondary metabolites have played a central role in species delimitation (Nelsen \& Gargas 2008). Molecular studies by Ekman and Tønsberg (2002) confirmed that it belongs to the family Stereocaulaceae. The genus Lepraria has been examined for the British Isles (Laundon 1992; Orange 1995), Norway (Tønsberg 1992, 2002), Finland (Lohtander 1994, 1995), Sweden (Lindblom 1995), Germany (Wirth \& Heklau 1995), Estonia (Saag \& Saag 1999), North America (Tønsberg 2004, 2007), Australia (Elix 2006), Belarus (Golubkov \& Kukwa 2006; Tsurykau et al. 2016), Italy (Zedda 2000, Baruffo et al. 2006), South America (Flakus \& Kukwa 2007, Bungartz et al. 2013), Greenland (Saag et al.
2007), South Korea (Joshi et al. 2010) and Latvia (Mežaka et al. 2012).

In Poland the genus Lepraria is represented by 17 species (Kukwa 2006). It has been studied in detail by Czarnota and Kukwa (2001), Kukwa (2001, 2002a, b, 2003, 2004a, b, 2006), Kukwa and Śliwa (2005), Osyczka and Stolarczyk (2005) and Osyczka et al. (2010). The data came from lowland (Gdansk region, Bialowieza Primeval Forest) and the Western Carpathians (Gorce Mts, Tatry Mts, Beskid Sądecki Mts, Pieniny Mts, Jaslo-Sanok Basin).

About 350 lichen species are known from the Knyszyn Forest (e.g., Bystrek \& Kolanko 2000; Cieśliński 2003). The lichen biota was thoroughly investigated by Bagińska and Motyka-Zgłobicka (1979), Bystrek and Anisimowicz (1981), Bystrek and Chwojko (1982), Cieśliński and Zielińska (1994), Cieśliński (1995, 2003), Bystrek and Kolanko (1996, 2000), Kolanko and Matwiejuk (1999, 2001a, b), Kolanko (2000, 2001, 2008, 
2009), Czyżewska et al. (2002) and Motiejūnaitè and Czyżewska (2008). Five Lepraria species [L. elobata Tønsberg, L. incana (L.) Ach., L. jackii Tønsberg, L. lobificans Nyl., L. vouaxii (Hue) R. C. Harris as Leproloma vouauxii (Hue) J. R. Laundon] were previously reported from the area but the species were treated without attention to secondary metabolites. Also, their records were limited to single localities.

The present paper includes data on six species of Lepraria (L. eburnea J. R. Laundon, L. elobata, L. incana, L. jackii, L. lobificans, L. vouaxii) recorded from the Knyszyn Forest. One species, L. eburnea, is newly reported for the studied area. All species were analyzed for the presence of lichen substances (TLC) and for their forest community and phorophyte type preferences. Seven lowland forest communities were included in the study.

\section{STUDY AREA}

The Knyszyn Forest is situated in Podlaskie Province, NE Poland (Fig. 1). It covers a large part $\left(1260 \mathrm{~km}^{2}\right)$ of the Wysoczyzna Białostocka upland. This forest is the second biggest forest complex in the Podlasie lowland, after the Bialowieza Forest. Over $60 \%$ of the forested area in the studied region is occupied by coniferous forest communities.

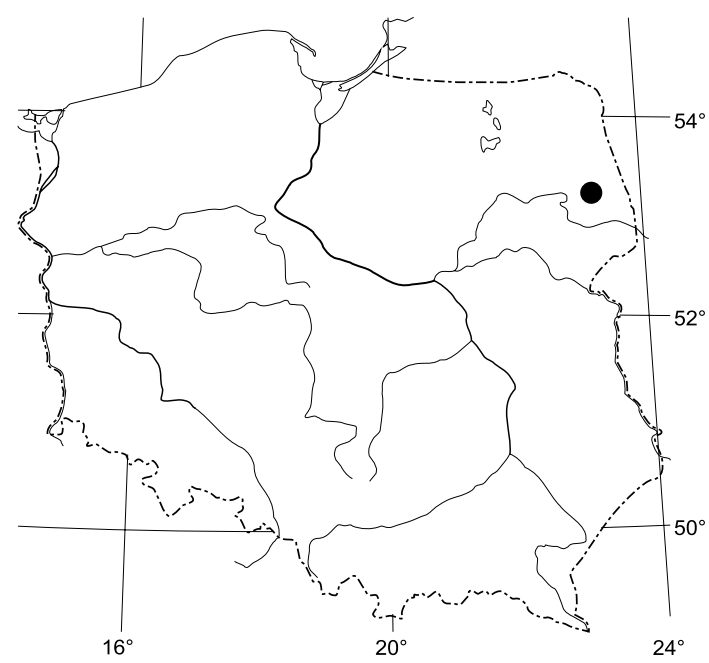

Fig. 1. Location of the study area.
Czerwiński (1995) described 15 forest communities and several supplementary communities from the Knyszyn Forest. The forest area is protected as Knyszyn Forest Landscape Park, established in 1988, and is a Nature 2000 EU Special Protection Area. The landscape park contains 20 nature reserves (Sokołowski 1991). The study was carried out in eight of them.

\section{MATERIAL AND METHODS}

In 2014-2015 I investigated the lichens of the Knyszyn Forest in eight nature reserves: Budzisk, Góra Pieszczana, Jesionowe Góry, Krzemianka, Krasne, Las Cieliczański, Stare Biele and Woronicza. The study was done in communities representing four types of deciduous forest (oak-hornbeam forest Tilio-Carpinetum Tracz. 1962, maple-linden slope forest Aceri-Tilietum Faber 1936, riparian alder forest Circaeo-Alnetum Oberd. 1953, alder carr Carici elongatae-Alnetum Koch 1926) and three types of coniferous forest: mixed oakspruce forest Querco-Piceetum (W. Mat. 1952) W. Mat. \& Polak. 1955, subcontinental pine forest PeucedanoPinetum W. Mat. (1962) W. Mat. \& J. Mat. 1973 and bog-spruce forest Sphagno girgensohnii-Piceetum Polak. 1962. Geographical coordinates were obtained from a GPS.

The research was done in two plots (each $20 \times 20 \mathrm{~m}$ ) demarcated in each forest plant community in the nature reserves, as follows:

1 - Budzisk Reserve $\left(53^{\circ} 16^{\prime} 44^{\prime \prime} \mathrm{N} 23^{\circ} 22^{\prime} 50^{\prime \prime}\right)$, forest plant communities: Aceri-Tilietum, Tilio-Carpinetum, Circaeo-Alnetum, Querco-Piceetum, Sphagno girgensohnii-Piceetum

2 - Jesionowe Góry Reserve ( $\left.53^{\circ} 20^{\prime} 47^{\prime \prime} \mathrm{N}, 23^{\circ} 17^{\prime} 28^{\prime \prime} \mathrm{E}\right)$, forest plant communities: Aceri-Tilietum, Querco-Piceetum

3 - Las Cieliczański Reserve $\left(53^{\circ} 10^{\prime} 23^{\prime \prime} \mathrm{N}\right.$, $23^{\circ} 22^{\prime} 17^{\prime \prime} \mathrm{E}$ ), forest plant community: Tilio-Carpinetum

4 - Góra Pieszczana Reserve $\left(53^{\circ} 12^{\prime} 19^{\prime \prime} \mathrm{N}\right.$, $23^{\circ} 34^{\prime} 58^{\prime \prime} \mathrm{E}$ ), forest plant community: PeucedanoPinetum

5 - Krasne Reserve $\left(53^{\circ} 11^{\prime} 44^{\prime \prime} \mathrm{N}, 23^{\circ} 18^{\prime} 14^{\prime \prime} \mathrm{E}\right)$, forest plant communities: Peucedano-Pinetum, Carici elongatae-Alnetum

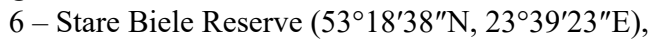
forest plant community: Carici elongatae-Alnetum

7 - Krzemianka Reserve $\left(53^{\circ} 17^{\prime} 71^{\prime \prime} \mathrm{N}, 23^{\circ} 06^{\prime} 72^{\prime \prime} \mathrm{E}\right)$, forest plant community: Circaeo-Alnetum

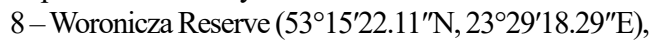
forest plant community: Sphagno girgensohnii-Piceetum. 
Table 1. Occurrence of the Lepraria species in Knyszyn Forest, by tree substrate and forest plant community type (Ag - Alnus glutinosa, $\mathrm{Bp}$ - Betula pendula, $\mathrm{Cb}$ - Carpinus betulus, $\mathrm{Fe}-$ Fraxinus excelsior, $\mathrm{Qr}-$ Quercus robur, $\mathrm{Pa}-$ Picea abies, $\mathrm{Ps}-$ Pinus sylvestris, $\mathrm{Pt}$ - Populus tremula, Tc - Tilia cordata).

\begin{tabular}{l|c|c|c|c|c|c|c}
\hline \multirow{2}{*}{ Forest plant community } & \multirow{2}{*}{ Locality } & \multicolumn{7}{|c}{ Species } & $\begin{array}{c}\text { Lepraria } \\
\text { eburnea }\end{array}$ & $\begin{array}{c}\text { Lepraria } \\
\text { elobata }\end{array}$ & $\begin{array}{c}\text { Lepraria } \\
\text { incana }\end{array}$ & $\begin{array}{c}\text { Lepraria } \\
\text { jackii }\end{array}$ & $\begin{array}{c}\text { Lepraria } \\
\text { lobificans }\end{array}$ & $\begin{array}{c}\text { Lepraria } \\
\text { vouaxii }\end{array}$ \\
\hline Tilio-Carpinetum & 1,3 & $\mathrm{Qr}$ & $\mathrm{Cb}, \mathrm{Tc}$ & $\mathrm{Cb}, \mathrm{Pt}, \mathrm{Tc}, \mathrm{Qr}$ & & $\mathrm{Cb}, \mathrm{Qr}, \mathrm{Pt}, \mathrm{Tc}$ & $\mathrm{Cb}, \mathrm{Qr}$ \\
\hline Aceri-Tilietum & 1,2 & & $\mathrm{Cb}$ & $\mathrm{Qr}, \mathrm{Tc}$ & & $\mathrm{Cb}, \mathrm{Fe}, \mathrm{Qr}, \mathrm{Tc}$ & \\
\hline Carici elongatae-Alnetum & 5,6 & & & $\mathrm{Ag}$ & & $\mathrm{Ag}$ & \\
\hline Circaeo-Alnetum & 1,7 & & & $\mathrm{Ag}$ & $\mathrm{Pa}$ & $\mathrm{Ag}$ & \\
\hline Querco-Piceetum & 1,2 & & $\mathrm{~Pa}$ & $\mathrm{Bp}, \mathrm{Qr}, \mathrm{Pa}$ & $\mathrm{Bp}, \mathrm{Pa}$ & & \\
\hline Peucedano-Pinetum & 4,5 & & $\mathrm{Ps}$ & $\mathrm{Ps}$ & $\mathrm{Ps}$ & $\mathrm{Ag}$ & \\
\hline Sphagno girgensohnii-Piceetum & 1,8 & & & $\mathrm{Bp}, \mathrm{Pa}$ & & $\mathrm{Pa}$ & \\
\hline
\end{tabular}

Data were collected from 14 study plots. The plots were sampled in the middle of the forest stands. In each plot, 10 trees with DBH $>0.05 \mathrm{~m}$ were selected randomly. The specimens were studied morphologically and anatomically by microscopy. Chemical analyses employed thin-layer chromatography (TLC) as described by Orange et al. (2001) and Flakus and Kukwa (2007). Lichen samples were extracted in acetone and the extract was spotted onto glass TLC plates pre-coated with Merck silica gel $60 \mathrm{~F} 254$, in solvent systems A (Culberson \& Ammann 1979) and C (Mietsch et al. 1994). Lichen species nomenclature follows Kukwa (2006), and forest plant community names follow Czerwiński (1995). Specimens are stored in the Herbarium of the Institute of Biology of the University of Bialystok.

\section{RESULTS AND DISCUSSION}

I recorded six species of Lepraria (L. eburnea, L. elobata, L. incana, L. jackii, L. lobificans, L. vouaxii) from the Knyszyn Forest (Table 1). Lepraria eburnea is a new species for the studied area. The most common species were Lepraria incana and L. lobificans. The richest lichen species diversity in the Knyszyn Forest was found on deciduous trees such as Carpinus betulus L. and Quercus robur L. (4 species), Tilia cordata Mill. (3 species) and on conifers such as Picea abies (L.) H. Karst. and Pinus sylvestris L. (3 species). The fewest Lepraria species were recorded on Alnus glutinosa (L.) Gaertn., Betula pendula Roth., Populus tremula L. and Fraxinus excelsior L. (1 sp.) (Table 1).
The forest community richest in species was oak-hornbeam Tilio-Carpinetum (5 species). Four species were found in pine Peucedano-Pinetum. Three taxa each were found in riparian alder Circaea-Alnetum and mixed oak-spruce QuercoPinetum. The fewest (2 species each) were found in maple-linden slope forest Aceri-Tilietum, alder carr Carici elongatae-Alnetum and spruce Sphagno girgensohnii-Piceetum (Table 2).

Table 2. Number of Lepraria species in different forest plant community types in the Knyszyn Forest.

\begin{tabular}{l|c|c|c}
\hline Forest plant community & Average & $\begin{array}{c}\text { Min.- } \\
\text { Max. }\end{array}$ & SD \\
\hline Tilio-Carpinetum & 3.05 & $1-5$ & 1.28 \\
\hline Aceri-Tilietum & 1.85 & $1-3$ & 0.79 \\
\hline Carici elongatae-Alnetum & 1.45 & $1-2$ & 0.50 \\
\hline Circaeo-Alnetum & 1.90 & $1-3$ & 0.78 \\
\hline Querco-Piceetum & 1.95 & $1-3$ & 0.82 \\
\hline Peucedano-Pinetum & 2.10 & $1-3$ & 0.72 \\
\hline $\begin{array}{l}\text { Sphagno girgensohnii- } \\
\text { Piceetum }\end{array}$ & 1.50 & 1 & 0.51 \\
\hline
\end{tabular}

\section{THE TAXA}

\section{Lepraria eburnea J. R. Laundon}

New for the Knyszyn Forest. Lepraria eburnea is a very rare species in this forest, growing on bark of deciduous trees in oak-hornbeam forest.

LICHEN SUBSTANCES: Chemotype (1) alectorialic acid \pm with associated substances, and with protocetraric acid.

OCCURRENCE THE STUDIED FOREST PLANT COMMUNITIES: Tilio-Carpinetum. 
TYPE OF PHOROPHYTE: Quercus robur.

LOCALITY: 3.

Notes. Lepraria eburnea is not very common in Poland (Kukwa 2003, 2006). The species has a rather wide habitat amplitude but prefers mediumacidic to basic substrates (Kukwa 2003, 2006); it grows on tree bark, concrete and rocks. The species has a boreal distribution (Tsurykau et al. 2016). It is common lichen in Estonian old-growth forests (Saag 2007). In the Knyszyn Forest this species is here reported for the first time, on bark of Quercus robur in oak-hornbeam forest. Wirth and Heklau (1995) reported L. eburnea mostly on Quercus, but Tønsberg (1992) found it more common on Alnus incana and Sorbus aucuparia, and rare on Populus tremula and Quercus spp.

\section{Lepraria elobata Tønsberg}

Lepraria elobata is a relatively common corticolous species in the Knyszyn Forest. It grows frequently on bark of deciduous trees but also was found on bark of coniferous trees. It grows in coniferous, deciduous and mixed forest.

LICHEN SUBSTANCES: Atranorin, stictic acid complex and zeorin.

OCCURRENCE THE STUDIED FOREST PLANT COMMUNITIES: Tilio-Carpinetum, Aceri-Tiletum, Querco-Piceetum and Peucedano-Pinetum.

TyPe OF PHOROPHYtes: Carpinus betulus, Picea abies, Pinus sylvestris and Tilia cordata.

Localities: 1, 2, 3, 4, 5.

Notes. In Poland, Lepraria elobata is considered to be one of the most common species of the genus Lepraria, especially in mountain regions (Kukwa 2003, 2006). It prefers acidic, meso- to oligotrophic bark of trees. It occurs almost exclusively in forests (Kukwa 2003).

\section{Lepraria incana (L.) Ach.}

Lepraria incana is relatively common in the Knyszyn Forest, found most often on bark of coniferous trees and bark of deciduous trees. This species prefers coniferous and mixed forests.

LICHEN SUBSTANCES: Divaricatic acid and zeorin.

OCCURRENCE IN THE FOREST PLANT COMMUNITIES: Tilio-Carpinetum, Aceri-Tiletum, Carici elongatae-
Alnetum, Peucedano-Pinetum, Querco-Piceetum and Sphagno girgensohnii-Piceetum.

TYPE OF PHOROPHYTES: Alnus glutinosa, Betula pendula, Carpinus betulus, Quercus robur, Picea abies, Pinus sylvestris, Populus tremula and Tilia cordata.

Localities: 1, 2, 3, 4, 5, 6, 7, 8 .

Notes. Lepraria incana is a common species in Europe (Tønsberg 2002; Mežaka et al. 2012, Kukwa 2006), occurring on many phorophytes (Kukwa 2006; Mežaka et al. 2012). Mežaka et al. (2012) found this species to prefer trees with relatively low bark $\mathrm{pH}$. Jüriado et al. (2009) also observed L. incana on more acidic substrates such as Betula spp. and Alnus glutinosa. Tsurykau et al. (2016) recorded L. incana mostly in coniferous forests ( $96 \%$ of the studied material) of varying insolation and humidity. In Estonia the old spruce-dominated forests may be especially suitable for L. incana on account of the shade, relatively high humidity, and low $\mathrm{pH}$ of spruce bark (Saag 2007).

\section{Lepraria jackii Tønsberg}

Lepraria jackii is a common lichen in the Knyszyn Forest. It grows almost exclusively on tree bark, especially that of coniferous and deciduous trees. It prefers pine and spruce forest.

LiCHEN SUBSTANCES: Atranorin, jackinic and roccellic acids.

OCCURRENCE THE STUDIED FOREST PLANT COMMUNITIEs: Circaeo-Alnetum, Querco-Piceetum and Peucedano-Pinetum.

TyPE OF PHOROPHYTES: Betula pendula, Picea abies and Pinus sylvestris.

Localities: 1, 2, 4, 5, 7.

Notes. Lepraria jackii is widespread throughout Poland, and relatively common (Kukwa 2002, 2006). The species grows on acidic and oligotrophic bark of trees. It prefers forests, especially well-insolated and rather dry pine and spruce forests (Kukwa 2003). Similar ecology was also reported for Belarus by Tsurykau et al. (2016). In Estonia, L. jackii is mainly epiphytic, preferring neutral substrate, and L. elobata belongs to the epiphyte group together with L. jackii but is more often acidophytic (Saag 2007). I recorded L. jackii 
mostly on bark of Picea abies, Pinus sylvestris and Betula pendula.

\section{Lepraria lobificans Nyl.}

Lepraria lobificans is a common lichen in the Knyszyn Forest. It was found mainly on bark of deciduous trees and very rarely on bark of coniferous trees (Picea abies). It prefers deciduous forests.

LICHEN SUBSTANCES: Atranorin, stictic acid complex and zeorin.

OCCURRENCE IN THE STUDIED FOREST COMMUNITIES: Tilio-Carpinetum, Aceri-Tilietum, Carici elongataeAlnetum, Circareo-Alnetum, Peucedano-Pinetum and Sphagno girgensohnii-Piceetum.

TyPe of PHOROPHYTEs: Alnus glutinosa, Carpinus betulus, Fraxinus excelsior, Quercus robur, Picea abies, Populus tremula and Tilia cordata.

Localities: 1, 2, 3, 4, 5, 6, 7, 8 .

Notes. In Poland, Lepraria lobificans is a common species and widely distributed, growing mainly on meso- to eutrophic, medium-acidic to basic substrates. It grows on bark of trees and also very often on rocks and saxicolous mosses. Lepraria lobificans is a hygrophilous lichen, growing usually in shade. As an epiphyte it prefers forest conditions, but also occurs in open areas, mostly near lakes or rivers. Lepraria lobificans very rarely occupies roadside trees (Kukwa 2003, 2006). In Scandinavia this species was recorded mostly in the European protected habitat known as 'Fennoscandian hemiboreal natural old broad-leaved forests rich in epiphytes' (Mežaka et al. 2012). In study area, L. lobificans prefers oak-hornbeam Tilio-Carpinetum. This suggests that L. lobificans prefers moderate humidity and moderately shady conditions.

\section{Lepraria vouaxii (Hue) R. C. Harris}

Lepraria vouauxii is a rare species in the Knyszyn Forest. It was found on bark of deciduous trees in Tilio-Carpinetum.

Lichen SUbSTANCES: Pannaric acid-6-methylester.

OCCURRENCE IN THE STUDIED FOREST COMMUNITIES: Tilio-Carpinetum.

TyPe of PHOROPHYTes: Carpinus betulus and Quercus robur.
Localities: $1,3$.

Notes. Lepraria vouaxii is not a common species in Poland; it is known mostly from open locations (Kukwa 2003). Most often it occupies well-insolated, meso- to eutrophic and mediumacidic to neutral bark of deciduous trees, and rarely other types of phorophytes (Kukwa 2006). Similar ecology was also reported for Belarus by Tsurykau et al. (2016), where the species grows on trees with medium-acidic to basic and nutrient-rich bark (Tsurykau et al. 2016). In Sardinia this species is considered to be a characteristic taxon of old oak woods (Zedda 2000).

ACKNOWLEDGEMENTS. I am grateful to the anonymous reviewers for helpful comments and suggestions on the manuscript. The study was supported by the statutory fund of the Department of Plant Ecology, Institute of Biology, University of Bialystok.

\section{REFERENCES}

BAgiŃska J. \& MotyKa-ZgŁobicka M. 1979. Lichens of Knyszyn area in the region Bialystok. Ann. Univ. Mariae Curie-Skłodowska, C, Biol. 34: 37-46 (in Polish with English summary).

Baruffo L., Zedda L., Elix J. A. \& Tretiach M. 2006. A revision of the lichen genus Lepraria s.lat. in Italy. Nova Hedwigia 83: 387-429.

Bungartz F., Hillmann G., Kalb K. \& Elix A. 2013. Leprose and leproid lichens of the Galapagos, with a particular focus on Lepraria (Stereocaulaceae) and Septotrapelia (Pilocarpaceae). Phytotaxa 150(1): 1-28.

Bystrek J. \& Anisimowicz A. 1981. Lichens of Budzisk reserve in Knyszyn Forest. Ann. Univ. Mariae CurieSkłodowska, C, Biol. 36: 109-117 (in Polish with English summary).

Bystrek J. \& Chwojko A. 1982. Lichens of Karczmisko reserve in Knyszyn Forest. Ann. Univ. Mariae CurieSkłodowska, C, Biol. 37: 215-222 (in Polish with English summary).

Bystrek J. \& Kolanko K. 1996. Lichens of the Jesionowe Góry Reserve in Poland. Acta Mycol. 31(2): 175-180.

Bystrek J. \& Kolanko K. 2000. Lichens (Lichenes) of Knyszyn Forest. Zakład Poligraficzny BS, Lublin (in Polish).

CIEŚLIŃSKI S. 1995. Lichens of Knyszyn Forest. In: A. CzerwiŃSKI (ed.), Puszcza Knyszyńska. Monografia przyrodnicza, pp. 173-202. Zespół Parków Krajobrazowych w Supraślu. 
CIEŚLIŃSKI S. 2003. Atlas of distributions of lichens (Lichenes) in North-Eastren Poland. Phytocoenosis 15 (N.S.), Supplementum Cartographiae Geobotanicae 15: 1-430.

CiEśLIŃSKI S. \& ZielińsKa J. 1994. Materials for the lichen flora of the Knyszyn Forest. Fragm. Florist. Geobot., Ser. Polon. 1: 49-61 (in Polish with English summary).

Culberson C. F. \& Ammann K. 1979. Standardmethode zur Dūnnschichtchromatographie von Flechtensubstanzen. Herzogia 5: 1-24.

Czarnota P. \& Kunwa M. 2001. Lichens of the genera Lepraria and Leproloma from the Gorce Mts (Western Carpathians, Poland) and note on lichenicolous fungus Paranectria oropensis found on Leproloma mebranaceum. Polish Bot. J. 46(2): 199-206.

Czerwiński A. 1995. Szata roślinna i pokrywa glebowa. In: A. Czerwiński (ed.), Puszcza Knyszyńska [Knyszyn Forest]. Monografia przyrodnicza, pp. 203-238. Zespół Parków Krajobrazowych w Supraślu.

Czyżewska K., Cieśliński S., Motiejunaite J. \& Kolanko K. 2002. The Budzisk nature reserve as a biocentre of lichen diversity in the Knyszyńska Large Forest (NE Poland). Acta Mycol. 37(1/2): 77-92.

EKman S. \& TønsberG T. 2002. Most species of Lepraria and Leproloma form a monophyletic group closely related to Stereocaulon. Mycol. Res. 106: 1262-1276.

Elix J. A. 2006. A new species of Lepraria (lichenized Ascomycota) from Australia. Australas. Lichenol. 58: 20-23.

Flakus A. \& Kukwa M. 2007. New species and records of Lepraria (Stereocaulaceae, lichenized Ascomycota) from South America. Lichenologist 39: 463-474.

Golubkov V. V. \& Kukwa M. 2006. A contribution to the lichen biota of Belarus. Acta Mycol. 42(1): 155-164.

Joshi Y., Wang X. Y., KoH J. J. \& HuR J. S. 2010. The lichen genus Lepraria (Stereocaulaceae) in South Korea. Mycotaxon 112: 201-217.

JÜRIADO I., LIIRA J. \& PAAL L. 2009. Diversity of epiphytic lichens in boreo-nemoral forests on the North-Estonian limestone escarpment: the effect of tree level factors and local environmental conditions. Lichenologist 41: 81-96.

Kolanko K. 2000. Lichens of nature reserves of Knyszyn Forest. Parki Narodowe i Rezerwaty Przyrody 9(3): 55-64 (in Polish with English summary).

Kolanko K. 2001. Epiphytic lichen-dominated communities in the Knyszyn Forest. Ann. Univ. Mariae Curie-Skłodowska, C, Biol. 56: 141-153.

Kolanko K. 2008. Lichens of Krasne reserve in Knyszyn Forest. Parki Narodowe i Rezerwaty Przyrody 27(3): 3-15 (in Polish with English summary).

Kolanko K. 2009. Lichens of the nature reserve of „Starodrzew Szyndzielski” in Knyszynska Forest Landscape Park (north-eastern Poland). Parki Narodowe i Rezerwaty Przyrody 28(2): 29-43 (in Polish with English summary).
Kolanko K. \& Matwiejuk A. 1999. Epixylic lichens of Knyszyn Forest and its surroundings. Fragm. Florist. Geobot., Ser. Polon. 6: 235-243.

Kolanko K. \& Matwiejuk A. 2001a. Lichens of Królowy Most and its surrounding in Knyszyn Forest. Fragm. Florist. Geobot., Ser. Polon. 8: 237-244 (in Polish with English summary).

Kolanko K. \& MatwiejuK A. 2001b. Lichens of hornbeam in Lanscape Park Knyszyn Forest (NE Poland). Parki Narodowe i Rezerwaty Przyrody 20(1): 25-33 (in Polish with English summary).

Kunwa M. 2001. Lichens from the genera Lepraria Ach. and Leproloma Nyl. ex Cromb. in the Gdańsk region. Acta Botanica Cassubica 2: 123-132 (in Polish with English summary).

Kunwa M. 2002a. Taxonomic notes on the lichen genera Lepraria and Leproloma. Ann. Bot. Fenn. 39: 225-226.

Kunwa 2002b. Porosty z rodzaju Lepraria i Leproloma w Puszczy Białowieskiej. Parki Narodowe i Rezerwaty Przyrody 21(3): 253-262.

Kukwa M. 2003. Lepraria Ach. - liszajec. In: W. FAŁTYNOwicz (ed.), The lichens, lichenocolous and allied fungi of Poland - an annotated checklist, pp. 171-174. W. Szafer Institute of Botany, Polish Academy of Sciences, Kraków.

KuKwa M. 2004a. Lepraria incana (L.) (Ach.). In: U. BIELCZYK, S. CieślińsKi \& W. FAŁTYNOWICZ (eds), Atlas of the geographical distribution of lichens in Poland. 4: 45-57. W. Szafer Institute of Botany Polish Academy of Sciences, Kraków.

Kunwa M. 2004b. Lichens of the genera Lepraria in the Tatra National Park. Parki Narodowe i Rezerwaty Przyrody 23(1): 3-12 (in Polish with English summary).

Kunwa M. 2006. The lichen genus Lepraria in Poland. Lichenologist 38(4): 293-305.

KuKwa M. \& Ślıwa L. 2005. The genus Lepraria (lichenized Ascomycota) in the Beskid Sądecki Mts (West Carpathians, S Poland). Polish Bot. J. 50(2): 163-184.

LAUNDON J. R. 1992. Lepraria in the British Isles. Lichenologist 24(4): 315-350.

LindBlom L. 1995. The genus Lepraria in the province of Skåne, southern most Sweden. Graphis Scripta 7(2): 49-60.

Lohtander K. 1994. The genus Lepraria in Finland. Ann. Bot. Fenn. 31(4): 223-231.

LOHTANDER K. 1995. The lichen genus Leproloma in Finland and some notes on the Lepraria neglecta group. Ann. Bot. Fenn. 32(1): 49-54.

Mežaka A., Brūmelis G., Piterāns A. \& Printzen C. 2012. Distribution of Lepraria in Latvia in relation to tree substratum and deciduous forest type. Ann. Bot. Fenn. 49(3): $162-170$. 
Mietsch E., Lumbsch H. T. \& Elix J. A. 1994. Wintabolites (Mactanolites for Windows) User's Manual. $2^{\text {nd }}$ ed. Universität Essen, Essen.

MotiejūNaité J. \& CzyżewsKa K. 2008. Additions to the biota of lichens and lichenicolous fungi of Poland, with a note on Lecania prasinoides in eastern and central Europe. Polish Bot. J. 53(2): 155-162.

Nelsen M. P. \& Gargas A. 2008. Phylogenetic distribution and evolution of secondary metabolites in the lichenized fungal genus Lepraria (Lecanorales: Stereocaulaceae). Nova Hedwigia 86: 115-131.

ORANGE A. 1995. The British species of Lepraria and Leproloma: chemistry andidentification. Bull. Brit. Lichen Soc. 76: $1-9$.

Orange A., James P. W. \& White F. J. 2001. Microchemical methods for the identification of Lichens. British Lichen Society, London.

OsyczKa P., Stolarczyk P. 2005. Lichens of the genus Lepraria in the Jasło-Sanok Basin (Western Carpathians, Poland). Fragm. Florist. Gobot. Polon. 12(2): 371-383 (in Polish with English summary).

OsyczKa P., KoziK J. \& KościelniaK R. 2010. Lichens from the genus Lepraria (Stereocaulaceae, lichenized Ascomycota) in the Pieniny National Park. Pieniny 11: 7-18 (in Polish with English summary).

SAAG L. 2007. The substrate preferences of epiphytic Lepraria species in old-growth forests in Estonia. Folia Cryptog. Estonica 43: 51-56.

SAAG L. \& SAAG A. 1999. The genus Lepraria (Lichenes imperfecti) in Estonia. Folia Cryptog. Estonica 34: 55-63.
SaAg L., Hansen E. S., SaAg A. \& Randlane T. 2007. Survey of Lepraria and Leproloma in Greenland. Mycotaxon 102: 57-90.

SaAg L., SaAg A. \& Randlane T. 2009. World survey of the genus Lepraria (Stereocaulaceae, lichenized Ascomycota). Lichenologist 41: 25-60.

SokoŁowski A. W. 1991. Natural protected objects of the Podlaskie Voivodeship. Wydawnictwo Wojewódzkiego Konserwatora Ochrony Przyrody, Białystok (in Polish).

TønsberG T. 1992. The sorediate and isidiate, corticolous, crustose lichens in Norway. Sommerfeltia 14: 1-331.

Tønsberg T. 2002. Notes on non-corticolous Lepraria s. lat. from Norway. Graphis Scripta 14(2): 45-51.

Tønsberg T. 2004: Lepraria. In: T. H. NASH III, B. D. Ryan., P. Diederich, C. Gries \& F. Bungartz (eds), Lichen Flora of the Greater Sonoran Desert Region. 2: 322-329. Lichens Unlimited, Arizona State University, Tempe, Arizona.

TønsberG T. 2007. Notes on the lichen genus Lepraria in Great Smoky Mountains National Park, southeastern North America: Lepraria lanata and L. salazinaca spp. nov. Opuscula Philolichenum 4: 51-54.

Tsurykau A., Golubkov V. V. \& Bely P. 2016. The genus Lepraria (Stereocaulaceae, lichenized Ascomycota) in Belarus. Folia Cryptog. Estonica 53: 43-50.

Wirth V. \& HeKlau M. 1995. Die epiphytischen Arten der Flechtengattungen Lepraria und Leproloma in BadenWürttemberg. Biblioth. Lichenol. 57: 443-457.

ZEDDA L. 2000. The lichen genera Lepraria and Leproloma in Sardinia (Italy). Cryptog. Mycol. 21(4): 249-267. 